\title{
Maximum intensity projection technique in the identification of small pulmonary nodules
}

Hiroaki SATOH ${ }^{\mathbf{1}}$ (ID)
Cite this article as: Satoh H. Maximum intensity projection technique in the identification of small pulmonary nodules. Tuberk Toraks 2020;68(2):195.

\section{Yazışma Adresi (Address for Correspondence)}

\section{Dr. Hiroaki SATOH}

Division of Respiratory Medicine,

Mito Medical Center, Tsukuba University,

Miya-machi 3-2-7,

Ibaraki, 310-0015, MITO - JAPAN

e-mail: hirosato@md.tsukuba.ac.jp
${ }^{1}$ Division of Respiratory Medicine, Mito Medical Center, Tsukuba University, Mito, Japan

${ }^{1}$ Tsukuba Üniversitesi Mito Tıp Merkezi, Gögüs Hastalıkları Bölümü, Mito, Japonya

CCopyright 2020 by Tuberculosis and Thorax.

Available on-line at www.tuberktoraks.org.com

Dear Editor,

We read with interest the report by Kizil and associates on diagnostic importance of maximum intensity projection technique in the identification of small pulmonary nodules with computed tomography, published in the number one issue of Tuberk Toraks (pages 35-42) (1). We would like to ask two questions. First, please let us know how this method is affected if there are diffuse changes in the underlying lungs, such as pulmonary fibrosis or emphysema? We would appreciate hearing about the authors' experience with nodular opacity in patients with such abnormalities in background lungs. Can we obtain similar results compared to the case where there is no abnormality in the background lungs? Second, please let us know how about this method in low density nodule such as ground-glass opacity. What about nodule with complicated concomitant opacities such as atelectasis and linear shadows? If you do not have any data, we do appreciate your theoretical guess and answer.

\section{REFERENCES}

1. Kizil PG, Hekimoglu K, Coskun M, Akcay S. Diagnostic importance of maximum intensity projection technique in the identification of small pulmonary nodules with computed tomography. Tuberk Toraks 2020;68(1):35-42. 